\title{
Receptor and enzyme expression for prostanoid metabolism in colorectal cancer related to tumor tissue $\mathrm{PGE}_{2}$
}

\author{
ANNIKA GUSTAFSSON, MARIANNE ANDERSSON, KRISTINA LAGERSTEDT, \\ CHRISTINA LÖNNROTH, SVANTE NORDGREN and KENT LUNDHOLM
}

\begin{abstract}
Department of Surgery, Surgical Metabolic Research Laboratory at Lundberg Laboratory for Cancer Research, University of Gothenburg, Sahlgrenska University Hospital, Gothenburg, Sweden
\end{abstract}

Received September 16, 2009; Accepted October 30, 2009

\author{
DOI: 10.3892/ijo_00000521
}

\begin{abstract}
Prostaglandins support progression of colorectal cancer by several mechanisms. This conclusion is based on epidemiological and drug intervention long-term studies or retrieved from animal and cell culture experiments. The aim of the present study was to map receptor and enzyme expression for prostanoid metabolism in the presence of high or low $\mathrm{PGE}_{2}$ content within colon cancer tissue at primary tumor operation and after short-term preoperative provision of non-steroidal anti-inflammatory drug (NSAID). Twentythree unselected patients with colon cancer were randomly selected to receive indomethacin (NSAID) or sham treatment for 3 days before surgery. Normal colon and tumor tissue were collected at operation for RNA extraction. Tissue $\mathrm{PGE}_{2}$ levels were measured by radioimmunoassay. Gene expression was quantified by microarray and real-time PCR. COX-1 expression increased proportionally to $\mathrm{COX}-2$ expression in colon cancer tissue from untreated patients. Indomethacin reduced $\mathrm{PGE}_{2}$ content in normal and tumor tissue with subsequently decreased IP, HPGD and PPAR $\gamma$ receptor expression in both tumor and normal colon tissue, while subtype $\mathrm{EP}_{1-4}$ receptors were not significantly influenced by indomethacin treatment. MPGES-1 expression was not related to overall $\mathrm{PGE}_{2}$ content in tumor and colon tissue, but decreased significantly in normal tissue during indomethacin exposure. Reduction of tumor tissue $\mathrm{PGE}_{2}$ was related to
\end{abstract}

Correspondence to: Professor Kent Lundholm, Department of Surgery, Sahlgrenska University Hospital, S-413 45 Gothenburg, Sweden

E-mail: kent.lundholm@surgery.gu.se

Abbreviations: EP, E-prostanoid; IP, I-prostanoid; FP, F-prostanoid; TP, T-prostanoid; HPGD, hydroxyprostaglandin dehydrogenase 15; mPTGES, microsomal prostaglandin E synthase (mPGES-1); PPAR $\gamma$, peroxisome proliferators-activated receptor; NSAID, nonsteroidal anti-inflammatory drug

Key words: prostaglandins, COX-2, colon cancer, non-steroidal anti-inflammatory drug significant alteration in expression of several hundred genes indicating decreased cell cycling and increased apoptosis during indomethacin treatment, probably related to upregulation of acute phase reactants in tumor tissue. Increased prostanoid activity in colon cancer tissue is related to cross-talk between tumor and stroma cells.

\section{Introduction}

Cyclooxygenase (COX) inhibition is linked to chemoprevention of colorectal cancer in part based on effects to attenuate tumor growth $(1,2)$. Our previous investigations have indicated that expression of COX-2 and subtype $\mathrm{EP}_{2}$ receptors in colorectal cancer tissue predict patient survival following intended curative operation (3). Thus, prostaglandins are involved in different metabolic pathways assumed to support tumor progression by alterations in cell proliferation, adhesion, migration, differentiation, apoptosis and angiogenesis $(1,2,4-11)$. The main function of NSAIDs is reversible inhibition of COX enzymes, where COX-1 is constitutively expressed in most tissues, while COX-2 is usually induced by growth factors and cytokines (12). A variety of such promoters induce $\mathrm{COX}-2$ and $\mathrm{PGE}_{2}$ synthase (mPGES-1) in tumor tissue $(13,14)$. Thus, cyclooxygenases are key enzymes in prostaglandin biosynthesis for conversion of arachidonic acid to the prostaglandin (PG) precursor $\mathrm{PGH}_{2}$, which is immediately converted to different prostaglandins $\left(\mathrm{PGH}_{2}, \mathrm{PGE}_{2}, \mathrm{PGH}_{2 \alpha}, \mathrm{PGI}_{2} /\right.$ prostacyclin or $\mathrm{TXA}_{2}$ ) depending on various cellular enzyme synthases (15). Net effects of COX enzymes in tumor tissue and cells depend on the balance between produced prostaglandins and interactions with corresponding receptors $(3,11,16-18)$. Enzymes catalyzing degradation of prostaglandins as 15-hydroxyprostaglandin dehydrogenase (HPGD) should also be of importance for overall tissue levels of $\mathrm{PGE}_{2}$ (19), although less evaluated in relationship to tumor progression (12). Thus, short-term COX-inhibition by provision of preoperative NSAID treatment of patients with colorectal cancer should offer a means to evaluate relationships between prostanoid production and the expression of corresponding receptors and other genes dependent on high $\mathrm{PGE}_{2}$ in colon cancer tissue. 


\section{Patients and methods}

Patients. Patients were randomized between 1998 and 2004 to receive NSAID or sham-treatment for 3 days before primary surgery for colorectal cancer as described elsewhere (20). NSAID treatment was indomethacin (Confortid, $50 \mathrm{mg}$ x 2, Alpharma, $n=9$ ) during three preoperative days together with proton pump inhibitor as prophylaxis (Nexium $40 \mathrm{mg}$ daily, Astra Zeneca), which was also provided as shamtreatment to control patients $(n=14)$. None of our patients received radiochemotherapy pre- or post-operatively according to standard criteria at our institution and individual review of patient study at the time of operation. The group of patients consisted of $43 \%$ males and $57 \%$ females with a median age of 77 years (range 56-85 years) at surgery. Their median survival was 11 months (range 6-55 months) following surgery according to a recent update of survival (June 2008) with 12 patients still alive. Tumors were histologically classified as Dukes A (4), Dukes B (9) and Dukes C (10) corresponding to stage I-III respectively. All patients with Dukes A stage were alive 2008 .

Tumor tissue material. Tumor and normal large bowel tissue samples were collected down to the serosa level and kept fresh frozen in liquid nitrogen and stored in $-80^{\circ} \mathrm{C}$ until analysis at primary operation. Certified pathologists staged all tumors. Tumor samples contained around 70-80\% tumor cells based on visual inspection.

Cell culture. Two well-differentiated human colorectal carcinoma cells lines were used (HT-29 and HCA-7 SigmaAldrich (St. Louis, MO, USA). Cells were cultured in McCoy's 5A medium (Fisher Scientific, Sweden) supplemented with $1.5 \%$ fetal calf serum (FCS), $100 \mathrm{U} / \mathrm{ml}$ penicillin, $100 \mu \mathrm{g} / \mathrm{ml}$ streptomycin and $292 \mu \mathrm{g} / \mathrm{ml} \mathrm{L-glutamine}$ (Bergman Labora, Sweden) and were maintained as monolayer in cell culture vials from Sigma-Aldrich in a humidified $(98 \%)$ incubator at $37^{\circ} \mathrm{C}$ with $5 \% \mathrm{CO}_{2}$ with a medium change once weekly. Indomethacin (Confortid, Alpharma ApS, Langenfeld, Germany) was diluted from a stock solution of $5 \mathrm{mg} / \mathrm{ml}$ and added to final concentration of $8.4 \mu \mathrm{M}$ in cell culture medium of study cells whereas control cells were provided saline of the same amount.

RNA extraction and cDNA synthesis. RNA was extracted with RNeasy ${ }^{\circledR}$ Fibrous Tissue Midi kit from Qiagen according to the protocol for Total RNA Isolation from Fibrous Tissue enclosed by the manufacturer. A quality control and concentration measurement of RNA was performed in Bioanalyzer from Agilent Technologies before cDNA synthesis. One $\mu \mathrm{g}$ of RNA was used in BD Advantage" RT-for-PCR kit (BD Bioscience) according to enclosed instruction.

Real-time PCR. TaqMan ${ }^{\circledR}$ Applied Biosystem (ABI PRISM ${ }^{\circledR}$ 7700) and LightCycler ${ }^{\circledR} 1.5$ Roche were used for real-time PCR reactions. All samples were performed in duplicate and related to expression of an appropriate housekeeping gene (GAPDH) confirmed separately (3). PCR-graded water was used as negative controls as confirmed in all analyses. Standard specimen used in all reactions was an untreated colon tumor (intermediate differentiation, Dukes' C) resected at Sahlgrenska University Hospital and applied in previous work. TaqMan gene expression assays (Applied Biosystem; Hs00168752, Hs00168754, Hs00168755, Hs00168761, Hs00377721 respectively Hs00153133) were used to determine relative expression of subtype $\mathrm{EP}_{1-4}$ receptors and COX-1/ COX-2 enzymes. cDNA (22.5 $\mu \mathrm{l})$ added to the reaction were diluted 1:100. Primers for GAPDH were purchased from Applied Biosystem as internal control for normalization of relative mRNA levels in prepared cDNA. TaqMan software was used to calculate $C_{t}$ values according to the comparative $C_{t}$-method (Applied Biosystem).

Expression of remaining receptors [DP-1, DP-2, FP, IP, TP, PPAR $\gamma]$ with primers described $(3,11)$, mPGES-1 [Hs-PTGES-1-SG (Qiagen)] and HPGD [Hs-HPGD-1-SG (Qiagen)] were analyzed in a LightCycler 1.5 (Roche). All except HPGD were analyzed with LightCycler FastStart DNA Master either by SYBR Green I or Plus kit from Roche according to attached protocol. HPGD was analyzed with Qiagen QuantiTect SYBR Green PCR kit as described by the manufacturer for the primer assay. Reactions were optimized for $\mathrm{MgCl}_{2}$ concentration, annealing temperature and primer concentration. All products were checked for correct amplicon size in Bioanalyzer 2100 from Agilent Technologies according to the protocol for DNA1000. Results were produced by use of the relative standard curve method. All samples were confirmed to be within the range of the standard curve. Results are given as relative gene expression per GAPDH expression obtained from the LightCycler data files.

Microarray expression profiling. Tumor mRNA from 6 indomethacin-treated patients and from 6 control patients were pooled respectively with 2 males and 4 females in each group [indo, $71 \pm 11(\mathrm{SD})$ years; ctrl, $74 \pm 5(\mathrm{SD})$ years]. Dukes staging in each group were A (1), B (2) and C (3). From indomethacin treated patients $400 \mathrm{ng}$ of tumor mRNA were labeled with Cy-3-dCTP (Amersham Biosciences) in a cDNA synthesis reaction with Agilent Fluorescent Direct Label, tumor mRNA from control patients (400 ng) was labeled with Cy-5-dCTP. Similar principles were used for normal colon tissue and HCA-7 cells. Pooled tumor cDNA from 6 indomethacin treated patients versus pooled tumor cDNA from 6 sham treated patients were hybridized on whole human oligo microarrays. The expression array (Whole Human Genome Oligo Microarray, Agilent Technologies) contained 44290 features including positive and negative control spots. Hybridization was performed during $18 \mathrm{~h}$ with test versus control cDNA in a dual-color experiment followed by post-hybridization washes according to in situ instructions (Hybridization Kit Plus, Agilent Technologies). Microarrays were dried with nitrogen gas in a laminar flow bench and images were quantified on Agilent G2565 AA microarray scanner. Fluorescence intensities were extracted using Feature Extraction 9.1 software program (Agilent Technologies). Dye-normalized, outlier- and background subtracted values were analyzed in GeneSpring (GX7.3.1) software program imported with the enhanced FE Agilent import. Two technical replicates of tumor tissue versus normal colon tissue were run. Hands-on-variation was checked in a 
Table I. Prostanoid receptor and enzyme expression in colorectal cancer and corresponding normal colon tissue in patients treated by indomethacin for 3 days preoperatively compared to untreated controls.

\begin{tabular}{|c|c|c|c|c|}
\hline Transcript & (Ligand) & $\begin{array}{c}\text { Indomethacin } \\
(9)\end{array}$ & $\begin{array}{c}\text { Control } \\
\text { (14) }\end{array}$ & $\begin{array}{c}\text { Mann-Whitney } \\
\text { p-value }\end{array}$ \\
\hline \multicolumn{5}{|l|}{ Receptor } \\
\hline \multicolumn{5}{|l|}{$\mathrm{EP} 1^{\mathrm{a}}$} \\
\hline $\mathrm{T}$ & & $10.3 \pm 6.6$ & $5.1 \pm 1.8$ & ns \\
\hline $\mathrm{N}$ & $\left(\mathrm{PGE}_{2}\right)$ & $20.6 \pm 9.4$ & $9.0 \pm 1.4$ & ns \\
\hline \multicolumn{5}{|l|}{$\mathrm{EP} 2^{\mathrm{a}}$} \\
\hline $\mathrm{T}$ & & $6.5 \pm 4.0$ & $4.3 \pm 1.1$ & ns \\
\hline $\mathrm{N}$ & $\left(\mathrm{PGE}_{2}\right)$ & $13.2 \pm 4.5$ & $7.7 \pm 0.6$ & ns \\
\hline \multicolumn{5}{|l|}{ EP3 ${ }^{a}$} \\
\hline $\mathrm{T}$ & & $5.9 \pm 5.1$ & $1.5 \pm 0.7$ & ns \\
\hline $\mathrm{N}$ & $\left(\mathrm{PGE}_{2}\right)$ & $8.6 \pm 3.8$ & $3.9 \pm 0.4$ & ns \\
\hline \multicolumn{5}{|l|}{$\mathrm{EP} 4^{\mathrm{a}}$} \\
\hline $\mathrm{T}$ & & $0.9 \pm 0.4$ & $0.5 \pm 0.1$ & ns \\
\hline $\mathrm{N}$ & $\left(\mathrm{PGE}_{2}\right)$ & $3.8 \pm 1.6$ & $2.1 \pm 0.2$ & ns \\
\hline \multicolumn{5}{|l|}{$\mathrm{DP} 1^{\mathrm{b}}$} \\
\hline $\mathrm{T}$ & & $2.6 \pm 1.0$ & $1.2 \pm 0.5$ & ns \\
\hline $\mathrm{N}$ & $\left(\mathrm{PGD}_{2}\right)$ & $7.4 \pm 0.8$ & $5.2 \pm 1.0$ & $<0.02$ \\
\hline \multicolumn{5}{|l|}{$\mathrm{DP} 2^{\mathrm{b}}$} \\
\hline $\mathrm{T}$ & & $2.0 \pm 0.6$ & $1.1 \pm 0.2$ & ns \\
\hline $\mathrm{N}$ & $\left(\mathrm{PGD}_{2}\right)$ & $6.8 \pm 1.1$ & $4.4 \pm 0.6$ & $<0.09$ \\
\hline \multicolumn{5}{|l|}{$\mathrm{FP}^{\mathrm{b}}$} \\
\hline $\mathrm{T}$ & & $1.3 \pm 0.7$ & $0.9 \pm 0.2$ & ns \\
\hline $\mathrm{N}$ & $\left(\mathrm{PGF}_{2 \alpha}\right)$ & $1.5 \pm 0.3$ & $1.8 \pm 0.2$ & ns \\
\hline \multicolumn{5}{|l|}{$\mathrm{IP}^{\mathrm{b}}$} \\
\hline $\mathrm{T}$ & & $0.6 \pm 0.3$ & $1.2 \pm 0.4$ & $<0.01$ \\
\hline $\mathrm{N}$ & $\left(\mathrm{PGI}_{2}\right)$ & $0.8 \pm 0.2$ & $2.5 \pm 0.3$ & $<0.0005$ \\
\hline \multicolumn{5}{|l|}{$\mathrm{TP}^{\mathrm{b}}$} \\
\hline $\mathrm{T}$ & & $0.5 \pm 0.2$ & $0.5 \pm 0.1$ & ns \\
\hline $\mathrm{N}$ & $\left(\mathrm{TXA}_{2}\right)$ & $0.8 \pm 0.1$ & $1.5 \pm 0.2$ & $<0.03$ \\
\hline \multicolumn{5}{|l|}{$\operatorname{PPAR} \gamma^{\mathrm{b}}$} \\
\hline $\mathrm{T}$ & & $1.0 \pm 0.3$ & $2.1 \pm 0.6$ & $<0.003$ \\
\hline $\mathrm{N}$ & $\left(15 \mathrm{~d}-\mathrm{PGJ}_{2}{ }^{\mathrm{c}}\right)$ & $1.0 \pm 0.2$ & $2.0 \pm 0.2$ & $<0.03$ \\
\hline \multicolumn{5}{|l|}{ Enzymes } \\
\hline \multicolumn{5}{|l|}{$\mathrm{COX}-1^{\mathrm{a}}$} \\
\hline $\mathrm{T}$ & & $0.2 \pm 0.06$ & $0.4 \pm 0.08$ & ns \\
\hline $\mathrm{N}$ & (PGs) & $6.4 \pm 3.7$ & $2.9 \pm 0.6$ & ns \\
\hline \multicolumn{5}{|l|}{$\operatorname{COX}-2^{\mathrm{a}}$} \\
\hline $\mathrm{T}$ & & $4.6 \pm 2.3$ & $2.5 \pm 0.7$ & ns \\
\hline $\mathrm{N}$ & (PGs) & $7.7 \pm 4.7$ & $3.5 \pm 1.3$ & ns \\
\hline \multicolumn{5}{|c|}{ mPGES- $1^{\mathrm{b}}$} \\
\hline $\mathrm{T}$ & & $0.9 \pm 0.4$ & $0.1 \pm 0.02$ & $<0.09$ \\
\hline $\mathrm{N}$ & $\left(\mathrm{PGE}_{2}\right)$ & $1.0 \pm 0.1$ & $0.7 \pm 0.1$ & $<0.001$ \\
\hline \multicolumn{5}{|l|}{ HPGD $^{\mathrm{b}}$} \\
\hline $\mathrm{T}$ & & $1.0 \pm 0.3$ & $4.6 \pm 2.4$ & $<0.02$ \\
\hline $\mathrm{N}$ & (PGs) & $9.0 \pm 1.1$ & $30.3 \pm 3.3$ & $<0.0001$ \\
\hline
\end{tabular}

Mean \pm SEM. ${ }^{a}$ Comparative $\mathrm{C}_{\mathrm{T}}$-method, 2- ${ }^{\Delta \Delta \mathrm{CT}}$, TaqMan 7700, Applied Biosystems. ${ }^{\mathrm{b}}$ Relative standard curve, LightCycler, Roche Diagnostics. ${ }^{\mathrm{c}} 15$-deoxy- $\Delta 12,14-\mathrm{PGJ}_{2}$, a hydration break-down product of $\mathrm{PGD}_{2}$. 
Table II. Number of significantly up- $(\uparrow)$ and down- $(\downarrow)$ regulated genes in colorectal tumor tissue and in cultured tumor cells (HCA-7) treated with indomethacin as described in Materials and methods.

\begin{tabular}{lccc}
\hline Array & Fold change 3 & Fold change 10 & Fold change 20 \\
\hline Tumor tissue $^{\mathrm{a}}$ & $209 \downarrow$ & $53 \downarrow$ & $9 \downarrow$ \\
& $72 \uparrow$ & & $7 \downarrow$ \\
HCA-7 cells in $_{\text {vitro }}$ a $^{\mathrm{a}}$ & $1022 \downarrow$ & $35 \uparrow$ & $14 \uparrow$ \\
\hline
\end{tabular}

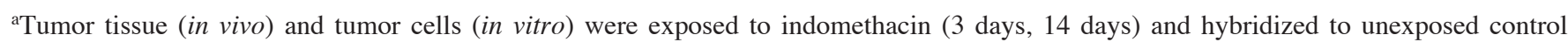
specimens.

'yellow experiment' where the same tumor RNA was labeled with both dyes competing for the same targets. Results from two merged technical replicates showed 41059 informative features out of 44290. Results from the 'yellow control experiment' with self-self competition indicated a mean ratio of $1.02 \pm 0.123$ (SD). 3-fold ratio changes in array analyses were regarded statistically significant alterations.

$P G E_{2}$-analysis. $\left.{ }^{[25} \mathrm{I}\right] \mathrm{PGE}_{2}$ assay system with magnetic separation (Amersham) was used for determination of $\mathrm{PGE}_{2}$ in tumor and normal colon tissue immediately homogenized in $0.1 \mathrm{M}$ Tris- $\mathrm{HCl}$ buffer, $\mathrm{pH} 7.4$, containing indomethacin to block arachidonic acid break-down. $\mathrm{PGE}_{2}$ was immediately extracted on Amprep C 18 mini-columns (Amersham RPN 1900) according to instructions (Amersham RPA 530) following acidification, ethanol addition and centrifugation of homogenized tissue. Radioimmunoassays were performed within 6 days after tissue sample collection. Mean values were calculated from duplicates. Measurement of $\mathrm{PGE}_{2}$ in cultured cells was performed with Biotrak ${ }^{\mathrm{TM}}$ enzyme immunoassay kit (EIA) according to protocol for standard EIA procedure.

Statistical analyses. Results are presented as mean \pm SEM in tables and figures. Patients were randomized by a computer based algorithm to receive indomethacin, accounting for age, sex and tumor stage, which made indomethacin and sham treated patients comparable in these respects and explains the uneven number between study and control groups (21). Power estimates $(\alpha<0.05, \beta=0.80)$ indicated that around 10 patients in each group would be enough to quantify significantly altered gene expression by real-time and qPCR according to our earlier experience (3). Statistical testing was performed by non-parametric tests (Mann-Whitney) $\mathrm{p}<0.05$ was regarded statistically significant and $\mathrm{p}<0.10$ a trend to significance in two-sided tests. This study protocol was approved by the board of ethics at University of Gothenburg (NCT00473980).

\section{Results}

Overall $\mathrm{PGE}_{2}$ production was $4.87 \pm 2.9 \mu \mathrm{g} / \mathrm{g}$ in tumor tissue and $0.32 \pm 0.18 \mu \mathrm{g} / \mathrm{g}$ in normal colon tissue from indomethacin treated patients $(\mathrm{p}<0.20)$, while untreated control patients displayed $34.4 \pm 11.1 \mu \mathrm{g} / \mathrm{g}$ in tumor tissue and $6.11 \pm 2.6 \mu \mathrm{g} / \mathrm{g}$ in normal colon tissue $(\mathrm{p}<0.01)$. Thus, indomethacin treatment decreased $\mathrm{PGE}_{2}$ content significantly in both tumor tissue $(\mathrm{p}<0.008)$ and normal colon tissue $(\mathrm{p}<0.01)$. Overall, gene expression appeared higher in normal colon tissue compared to tumor tissue (Tables I and IV).

Gene expression and indomethacin treatment. Pre-operative indomethacin treatment for 3 days increased tumor tissue mPGES-1 expression, while IP, PPAR $\gamma$ and HPGD expression were decreased compared to tumor tissue from control patients. Indomethacin treatment increased expression of DP1, DP2 and mPGES-1 in normal colon tissue, whereas expression of IP, TP, HPGD and PPAR $\gamma$ receptors were significantly decreased (Table I).

Array profiling analysis, filtered with a 3-fold change $(\mathrm{p}<0.01)$, displayed 281 genes with altered expression during indomethacin treatment (72 up-regulated and 209 downregulated; $\mathrm{p}<0.05$ ) (Table II). Gene pathways for tumor progression indicated that 30 genes were affected related to apoptosis while 60 significantly altered genes were related to proliferation. Similar conclusions appeared when expression data were incorporated into cell-algorithms defined by the Gene Spring computer program (KEGG components) indicating that apoptosis and cell cycle activities were significantly affected, where down-regulation of cell survival factors appeared to promote balance towards apoptosis and withdrawal of external growth factors seemed to decrease activation through glycogen synthase $3 ß$ kinase (not shown). Indomethacin also affected significantly IL3 (CSF2RB $\downarrow$, CISH $\downarrow$, BCL2L1 $1 \downarrow$ ) and IL7 pathways (BCL2L11 $\downarrow$, IRS2 $\downarrow$ ) (not shown). Top 10 up-regulated genes involved mainly markers for acute phase reactants and immune response as reported (20), while top 10 most down-regulated genes had mainly undefined functions (Table III).

Endogenous $P G E_{2}$ and prostanoid receptor expression. Shamtreated control patients were divided into two groups based on high $(n=6)$ and low $(n=5) P_{2}$ concentration in tumor tissue $(\mathrm{p}<0.01)$. Receptor and enzyme expression were not related to overall high or low $\mathrm{PGE}_{2}$ content in tumor tissue, 
Table III. Expression of 10 most up- and down-regulated genes in colorectal tumor tissue from indomethacin-treated patients compared to untreated controls.

\begin{tabular}{|c|c|c|c|}
\hline Gene name & $\begin{array}{c}\text { Gene symbol } \\
\text { (GeneID) }\end{array}$ & $\mathrm{FC}$ & Protein function \\
\hline
\end{tabular}

\section{Upregulated}

Melanoma inhibitory activity MIA

Lectin, galactoside-binding, soluble, 2

Serum amyloid A1, A2

Major histocompatibility complex, class II, DR $B 3$

Remodelling and spacing factor 1

Major histocompatibility complex, class II, DQ $ß 1$

Major histocompatibility complex, class II, DQ $\alpha 1$

Retinoic acid receptor responder 1

Desmin

Major histocompatibility complex, class II, DR 34

Downregulated

A kinase (PRKA) anchor protein 14
Regenerating islet-derived $3 \gamma$
Syntaxin binding protein 6 (amisyn)
Tripartite motif-containing 40
THC1536208
A_23_B561191
Human 5.5 kb mRNA
Metallothionein 1E
Bx379562 4.5 placenta
NM_001008387.1

LGALS2 (3957)

SAA1 (6288), SAA2 (6289)

HLA-DRB3 (3125) ${ }^{\mathrm{a}}$

\section{RSF1}

HLA-DQB1 (3119)

HLA-DQA1 (3117)a

RARRES1 (5918)

DES (1674)

HLA-DRB4 (3126) ${ }^{\mathrm{a}}$
19 Matrix protein interactions

17 Bind to lymphotoxin- $\alpha$

15, 14 Acute phase reactants

14 Immune defense, peptide presenter

11 Transcription regulation

11 Immune defense, peptide presenter

11 Immune defense, peptide presenter

10 Binds retinoic acid, involved in differentiation

10 Muscle filament

10 Immune defense, peptide presenter

$\begin{array}{lll}\text { AKAP14 (158798) } & -25 & \text { Binds protein kinase A (PKA) } \\ \text { REG3G (130120) } & -22 & \text { Growth stimulating on pancreatic B cells } \\ \text { STXBP6 (29091) } & -20 & \text { Regulation of SNARE } \\ \text { TRIM40 (135644) } & -20 & - \\ \text { CR745651 } & -20 & - \\ \text { A_23_P61191 } & -20 & - \\ \text { U09197 } & -20 & - \\ \text { MT1E (4493) } & -18 & \text { Antioxidant, energy metabolism } \\ \text { CR598849 } & -18 & - \\ \text { KHSRP } & -18 & \text { RNA and protein interaction }\end{array}$

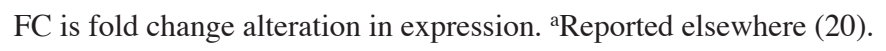

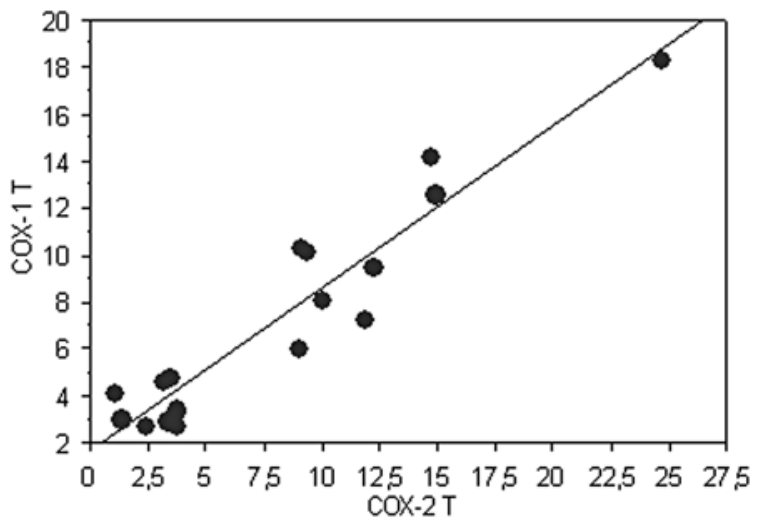

Figure 1. The relationship between COX-1 and COX-2 expression in colon cancer tissue from untreated patients. but expression of $\mathrm{EP}_{3}(\mathrm{p}<0.07), \mathrm{EP}_{4}(\mathrm{p}<0.02)$ and $\mathrm{TP}(\mathrm{p}<0.03)$ were significantly altered in normal colon tissue accounting for low $\mathrm{PGE}_{2}$ content (Table IV). COX-1 expression was highly related to COX-2 expression in tumor tissue (Fig. 1). This was explained by a proportional increase of COX-1 in tumors with high $\mathrm{COX}-2$, while there was no correlation between COX-1 and COX-2 expression in tumors with low COX-2 expression (not shown).

Effects of indomethacin on cultured tumor cells. Indomethacin treatment during 14-days of cultured cells reduced production and medium levels of $\mathrm{PGE}_{2}$ in $\mathrm{HCA}-7$ cells (indomethacin treated $<2.5 \mathrm{pg} / \mathrm{ml}$; control cells $125 \mathrm{pg} / \mathrm{ml}$ medium) while HT-29 cells remained low in $\mathrm{PGE}_{2}$ production with or without indomethacin $(<2.5 \mathrm{pg} / \mathrm{ml})$. Effects of constant indomethacin exposure to HCA-7 cells on EP receptors and COX enzyme 
Table IV. Prostanoid receptor and enzymes expression in colorectal cancer and corresponding normal colon tissue from selected patients with $\mathrm{PGE}_{2}$ levels above (high) or below (low) the median value in tumor tissue from untreated controls $(\mathrm{p}<0.01)$.

Transcript (Ligand) Low $\mathrm{PGE}_{2}$

(5)

\section{Receptor}

EP1 ${ }^{a}$

$\mathrm{T}$

N

EP2 ${ }^{a}$

$\mathrm{T}$

N

EP3 ${ }^{a}$

$\mathrm{T}$

$\mathrm{N}$

EP4 ${ }^{\mathrm{a}}$

$\mathrm{T}$

N

DP1 ${ }^{\text {b }}$

$\mathrm{T}$

N

DP2 ${ }^{\mathrm{b}}$

$\mathrm{T}$

N

$\mathrm{FP}^{\mathrm{b}}$

$\mathrm{T}$

N

$\mathrm{IP}^{\mathrm{b}}$

$\mathrm{T}$

N

$\mathrm{TP}^{\mathrm{b}}$

$\mathrm{T}$

N

PPAR $\gamma^{b}$

$\mathrm{T}$

N

$\left(15 d-\mathrm{PGJ}_{2}{ }^{\mathrm{c}}\right)$
$4.5 \pm 2.0$

$8.2 \pm 1.9$

$5.5 \pm 2.6$

$6.9 \pm 0.9$

$1.4 \pm 0.6$

$3.0 \pm 0.7$

$0.6 \pm 0.2$

$2.7 \pm 0.4$

$0.7 \pm 0.5$

$3.6 \pm 0.7$

$1.0 \pm 0.3$

$5.1 \pm 0.4$

$1.3 \pm 0.5$

$1.5 \pm 0.2$

$1.2 \pm 0.3$

$2.1 \pm 0.3$

$0.7 \pm 0.2$

$0.9 \pm 0.2$

$0.2 \pm 0.03$

$0.9 \pm 0.2$

$0.3 \pm 0.2$

$2.7 \pm 0.9$

$2.5 \pm 1.3$

$1.7 \pm 0.6$

mPGES-1 ${ }^{\mathrm{b}}$

$\mathrm{T}$

N

HPGD $^{\mathrm{b}}$

$\mathrm{T}$

N
(PGs)

(PGs)

$\left(\mathrm{PGE}_{2}\right)$

(PGs)
$1.4 \pm 0.4$

$1.7 \pm 0.2$

$8.1 \pm 6.7$
High $\mathrm{PGE}_{2}$

(6)

$5.9 \pm 4.1$

$7.6 \pm 1.5$

$4.2 \pm 1.5$

$7.5 \pm 0.7$

$2.1 \pm 1.6$

$4.6 \pm 0.6$

$0.5 \pm 0.2$

$1.4 \pm 0.1$

$1.8 \pm 1.1$

$6.4 \pm 2.1$

Mann-Whitney p-value

-

ns

ns

ns

ns

ns

$<0.07$

ns

$<0.02$

ns

ns

$1.2 \pm 0.3$

$3.5 \pm 0.9$

ns

ns

$0.8 \pm 0.4$

$2.1 \pm 0.2$

ns

ns

$1.7 \pm 0.8$

$2.9 \pm 0.5$

ns

ns

$0.5 \pm 0.2$

$2.0 \pm 0.4$

ns

$<0.03$

$0.1 \pm 0.03$

$0.7 \pm 0.01$

ns

ns

$0.4 \pm 0.1$

ns

$2.1 \pm 0.6$

ns

$3.3 \pm 1.0 \quad$ ns

$3.8 \pm 1.5 \quad$ ns

$2.6 \pm 1.5$

$2.2 \pm 0.3$

ns

ns

$3.3 \pm 0.9$

$34.3 \pm 6.0$

ns

ns

Mean \pm SEM. ${ }^{a}$ Comparative $\mathrm{C}_{\mathrm{T}}$-method, 2- ${ }^{\Delta \Delta \mathrm{CT}}$, TaqMan 7700, Applied Biosystems. ${ }^{\mathrm{b}}$ Relative standard curve, LightCycler, Roche Diagnostics. ${ }^{\mathrm{c}} 15$-deoxy- $\Delta 12,14-\mathrm{PGJ}_{2}$, a hydration break-down product of $\mathrm{PGD}_{2}$. 

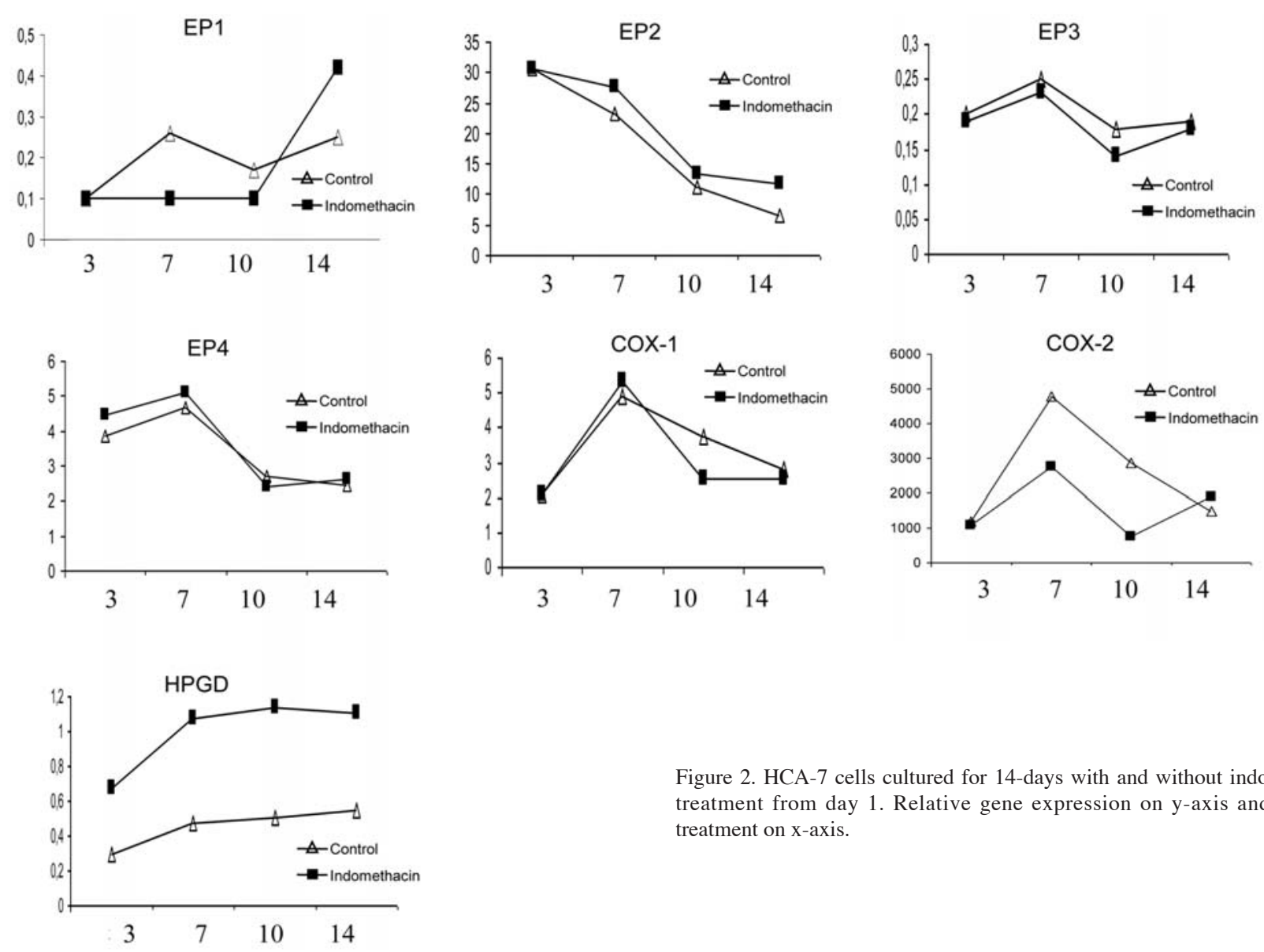

Figure 2. HCA-7 cells cultured for 14-days with and without indomethacin treatment from day 1. Relative gene expression on $y$-axis and days of treatment on $\mathrm{x}$-axis.

expression were negligible compared to culture time whereas COX-2, HPGD and EP1 subtype receptor expression displayed alterations related to altered $\mathrm{PGE}_{2}$ exposure (Fig. 2). Unexpectedly, expression of HPGD was overall higher in the presence of indomethacin compared to untreated cells. Also, alterations in up-regulation of genes appeared more frequent in cultured cells compared to findings in tumor tissue during indomethacin exposure (Table II).

\section{Discussion}

Animal experiments and clinical investigations have provided a large body of information on the role of prostanoid influence in carcinogenesis and progression of colorectal cancer, although precise mechanisms are not understood (12). In this context earlier studies in our laboratory have relied on effects by indomethacin to inhibit cyclooxygenase activity in tumor and host cells, although it is likely that prostaglandin independent pathways occur and that COX-2 inhibitors may have different overall effects compared to mixed COX-1/ COX-2 inhibition $(1,2,22,23)$. Our previous studies have indicated that indomethacin attenuates whole body systemic inflammation, which may lead to prolonged survival in patients with systemic cancer (24). Tumor-host interactions at both systemic and local tumor levels are nowadays comparatively well understood representing complex networks of signaling between tumor cells and surrounding stroma including inflammatory and endothelial cells (25). Numerous studies have shown that prostanoids, particularly
$\mathrm{PGE}_{2}$, are second messengers in both cell to cell communication and involve intracellular reactions related to Gcoupled protein receptors. It is thus evident that systemic reactions such as progressive weight loss, anorexia and systemic inflammation relate to prostaglandin activities in various organs including tumor tissue (26). Therefore, it should be possible to specifically attenuate local and systemic progressive disease by understanding ligand receptor activities in prostanoid related metabolism and subsequently confirm main signaling pathways $(12,23,27)$. In this context it is important to emphasize that up-regulation of COX-2 expression in tumor tissue is usually not a general phenomenon among tumor cells $(3,28)$. Indeed, it is a scattered cellular phenomenon within colon cancer tumors showing 'hot spots' of COX-2 expression (28), reflected by overall lower content of transcripts for prostanoid related proteins in tumor tissue compared to normal colon tissue (3); contrary to findings in cell cultures of colon cancer (29). Therefore, it is most likely that upregulation of COX-2 in some tumor cells explains the majority of increased $\mathrm{PGE}_{2}$ content in tumor tissue beside its decreased degradation, although this assumption has not yet been directly confirmed in clinical specimens. However, tumor stroma cells also express considerable amounts of COX-2 for $\mathrm{PGE}_{2}$ synthesis in colorectal tumor tissue (28). Accordingly, we have reported that both $\mathrm{COX}-1$ and COX-2 protein correlate to $\mathrm{PGE}_{2}$ content in colon cancer tissue (28). The present results demonstrate that $\mathrm{COX}-1$ expression was proportionally increased to $\mathrm{COX}-2$ expression in colon cancer tissue. This fact explains why unspecific cyclooxygenase 
inhibitors attenuate tumor progression effectively $(2,20,24)$. It has also been reported that mPGES-1 is over-expressed in colorectal cancer responsible for $\mathrm{PGE}_{2}$ production (14), although increased $\mathrm{PGE}_{2}$ levels in tissue may as well depend on $\mathrm{PGE}_{2}$ break-down by HPGD. Accordingly, HPGD expression was low in tumor tissue from our present patients when compared to overall levels in their normal colon tissue. HPGD was also significantly decreased in response to indomethacin treatment in vivo, but showed unexpectedly an opposite response in cultured colon cancer cells (Fig. 2).

Prostanoid receptor expressions were to some extent affected by indomethacin treatment with reduced IP receptor expression in both tumor and normal colon tissue. IP is activated by prostacyclin $\left(\mathrm{PGI}_{2}\right)$ and has been reported to inhibit apoptosis in colonic epithelial cells $(30,31)$. Receptors for $\mathrm{PGD}_{2}$ (DP1 and DP2) showed increased expression in normal colon tissue during indomethacin treatment with evidence that indomethacin may have direct agonistic effect on $\mathrm{DP} 2$ receptor (32). Interestingly, $\mathrm{PGD}_{2}$ may have several effects in tumor tissue as decreased proliferation including pro- and anti-inflammatory actions with significant effects on immune reactions (33-36). Thus, different effects within a tumor compartment are likely dependent on the type of $\mathrm{PGD}_{2}$ receptor activation (DP1, DP2 and PPAR $\gamma$ ). PPAR $\gamma$ is usually recognized as a tumor suppressor (37), but indomethacin decreased its expression in both normal and tumor tissue (Table I). Also, expression of $\mathrm{EP}_{3}, \mathrm{EP}_{4}$ and $\mathrm{TP}$ in normal colon tissue were significantly related to net $\mathrm{PGE}_{2}$ production, but not so in tumor tissue.

We also investigated receptor and enzyme expression (subtype $\mathrm{EP}_{1-4}, \mathrm{COX}-1, \mathrm{COX}-2$, HPGD) in cultured colon cancer cells (HCA-7) in the presence of indomethacin, since $\mathrm{PGE}_{2}$ is regarded a major prostaglandin produced by tumor cells (2). Specific effects by indomethacin on EP receptor expression were not apparent except for $\mathrm{EP}_{1}$. However, indomethacin decreased temporarily expression of COX-2 and increased expression of HPGD in cultured tumor cells, but decreased HPGD expression in tumor tissue in vivo in contrast to present and previous information in cultured cells (38). Findings of enhanced HPGD activity and content have been observed in human medullary thyroid cancer and tumor C cells during indomethacin treatment $(39,40)$. Thus, discrepant results on HPGD expression in vitro and in vivo during indomethacin exposure emphasize difficulties to compare results from in vivo mixed tissues with findings in isolated cell cultures. This may illustrate limitation for interpretations of in vivo observations, but represents also the strength to reflect net effects among various cells in complexed tumor tissue; for example that tumor tissue expression of COX-2 and $\mathrm{EP}_{2}$ receptors predicted survival without being overall increased in tumor tissue (3), a phenomenon that emphasizes the role of stroma cells for tumor prostanoid metabolism.

Preoperative treatment with indomethacin for 3 days caused alterations in expression of numerous genes with different functions, assessed on pooled RNA from Dukes A-C tumors. Our purpose with gene profiling was to map appearance/disappearance of gene transcripts in relationship to high and low $\mathrm{PGE}_{2}$ content in tumor tissue despite tumor stage, as earlier reported for normal colon tissue after longterm treatment with celecoxib (41). Similarly, an earlier report from our group displayed impacts on HLA antigen expression including markers for immune defense reactions (20), in agreement with a report by Auman et al who pretreated patients with celecoxib for 7 days and found evidence of increased immune response (42). Such results are present among listed top ten up-regulated genes, which seemed to be related in general to promotion of acute phase and immune reactions (Table III). However, melanoma inhibitory activity (MIA) was upregulated by indomethacin. Expression of MIA is an early event in melanoma development and correlates with tumor progression and tumor invasiveness secondary to cell-matrix interactions (43). The role of MIA and its eventual role in immune interactions within colorectal tumor tissue remains to be elucidated. Others have reported that MIA is highly expressed in pancreatic carcinoma compared to normal pancreas (44). However, the seemingly negative appearance of MIA from low tissue levels in colon cancer during NSAID treatment is obviously cancelled out in some respect $(8,20,24)$. We can also provide information on alterations in gene expression and net $\mathrm{PGE}_{2}$ production in tumor tissue affecting pronounced alterations in apoptosis (LGALS2), differentiation (RARRES1) and regulation of energy metabolism (AKAP14, MT1E) in agreement with findings occurring in animal tumor models (45). Gene algorithm analysis suggested apoptosis as the clearly affected pathway in tumor tissue in the present patients, which agrees with overall findings in tumor tissue in cell culture experiments (29). Seen together, our computer based algorithm analyses indicated that extrinsic 'survival factors' were particularly down-regulated to promote net apoptosis, together with decreased external growth factor exposure for stimulation of cell cycling (24). A speculative suggestion is that stroma cells are influenced to decrease external stimulation of tumor cells and promote apoptosis during cyclooxygenase inhibition (28).

In conclusion, the present clinical findings emphasized that prostanoid metabolism is complex in colon cancer tissue and involves several hundred genes, which appear to control local tumor growth and net immune response $(20,42)$, cell proliferation, differentiation, energy metabolism and apoptosis as earlier reported for normal colon tissue (41). However, alterations in tumor tissue gene expression following indomethacin treatment were not entirely similar to alterations in normal colon tissue from the same patients or to findings in cultured colon cancer cell lines. This and other phenomena point to the importance of stroma cells (28). A detailed understanding of the cross-talk between stroma and tumor cells and the signaling pathways behind altered net $\mathrm{PGE}_{2}$ production in colon cancer tissue may represent future targets for attenuation of local tumor growth.

\section{Acknowledgements}

This study was supported in part by grants from the Swedish Cancer Society (2014), the Swedish Research Council (08712), Assar Gabrielsson Foundation (AB Volvo), Jubileumskliniken Foundation, IngaBritt \& Arne Lundberg Research Foundation, Swedish and Gothenburg Medical 
Societies, the Medical Faculty, University of Gothenburg and Sahlgrenska University Hospital Foundation.

\section{References}

1. Gelin J, Andersson C and Lundholm K: Effects of indomethacin, cytokines, and cyclosporin A on tumor growth and the subsequent development of cancer cachexia. Cancer Res 51: 880-885, 1991.

2. Cahlin C, Gelin J, Andersson M, Lönnroth C and Lundholm K: The effects of non-selective, preferential-selective and selective COX-inhibitors on the growth of experimental and human tumors in mice related to prostanoid receptors. Int J Oncol 27: 913-923, 2005.

3. Gustafsson A, Hansson E, Kressner U, Nordgren S, Andersson M, Wang W, Lonnroth C and Lundholm K: EP(1-4) subtype, COX and PPARgamma receptor expression in colorectal cancer in prediction of disease-specific mortality. Int J Cancer 121: 232-240, 2007.

4. Cao Y and Prescott SM: Many actions of cyclooxygenase-2 in cellular dynamics and in cancer. J Cell Physiol 190: 279-286, 2002.

5. Pradono P, Tazawa R, Maemondo M, Tanaka M, Usui K, Saijo Y, Hagiwara K and Nukiwa T: Gene transfer of thromboxane A(2) synthase and prostaglandin I(2) synthase antithetically altered tumor angiogenesis and tumor growth. Cancer Res 62: 63-66, 2002.

6. Wang D and Dubois RN: Prostaglandins and cancer. Gut 55: 115-122, 2006

7. Hull MA, Ko SC and Hawcroft G: Prostaglandin EP receptors: targets for treatment and prevention of colorectal cancer? Mol Cancer Ther 3: 1031-1039, 2004.

8. Tsujii M, Kawano S and DuBois RN: Cyclooxygenase-2 expression in human colon cancer cells increases metastatic potential. Proc Natl Acad Sci USA 94: 3336-3340, 1997.

9. Sheng H, Shao J, Morrow JD, Beauchamp RD and DuBois RN: Modulation of apoptosis and $\mathrm{Bcl}-2$ expression by prostaglandin $\mathrm{E} 2$ in human colon cancer cells. Cancer Res 58: 362-366, 1998.

10. Sheng H, Shao J, Washington MK and DuBois RN: Prostaglandin E2 increases growth and motility of colorectal carcinoma cells. J Biol Chem 276: 18075-18081, 2001.

11. Gustafsson A, Hansson E, Kressner U, Nordgren S, Andersson M, Lonnroth $\mathrm{C}$ and Lundholm $\mathrm{K}$ : Prostanoid receptor expression in colorectal cancer related to tumor stage, differentiation and progression. Acta Oncol: 1107-1112, 2007.

12. Greenhough A, Smartt HJ, Moore AE, Roberts HR, Williams AC Paraskeva $\mathrm{C}$ and Kaidi A: The COX-2/PGE2 pathway: key roles in the hallmarks of cancer and adaptation to the tumour microenvironment. Carcinogenesis 30: 377-386, 2009.

13. Herschman HR: Prostaglandin synthase 2. Biochim Biophys Acta 1299: 125-140, 1996.

14. Yoshimatsu K, Golijanin D, Paty PB, Soslow RA, Jakobsson PJ De Lellis RA, Subbaramaiah K and Dannenberg AJ: Inducible microsomal prostaglandin E synthase is overexpressed in colorectal adenomas and cancer. Clin Cancer Res 7: 3971-3976, 2001.

15. Gupta RA and Dubois RN: Colorectal cancer prevention and treatment by inhibition of cyclooxygenase-2. Nat Rev Cancer 1: 11-21, 2001.

16. Yang VW, Shields JM, Hamilton SR, Spannhake EW, Hubbard WC, Hylind LM, Robinson CR and Giardiello FM: Size-dependent increase in prostanoid levels in adenomas of patients with familial adenomatous polyposis. Cancer Res 58: 1750-1753, 1998.

17. Rigas B, Goldman IS and Levine L: Altered eicosanoid levels in human colon cancer. J Lab Clin Med 122: 518-523, 1993.

18. Pinto S, Gori L, Gallo O, Boccuzzi S, Paniccia R and Abbate R: Increased thromboxane A2 production at primary tumor site in metastasizing squamous cell carcinoma of the larynx. Prostaglandins Leukot Essent Fatty Acids 49: 527-530, 1993.

19. Yan M, Rerko RM, Platzer P, Dawson D, Willis J, Tong M, Lawrence E, Lutterbaugh J, Lu S, Willson JK, Luo G, Hensold J, Tai HH, Wilson K and Markowitz SD: 15-Hydroxyprostaglandin dehydrogenase, a COX-2 oncogene antagonist, is a TGF-betainduced suppressor of human gastrointestinal cancers. Proc Natl Acad Sci USA 101: 17468-17473, 2004.
20. Lönnroth C, Andersson M, Arvidsson A, Nordgren S, Brevinge H, Lagerstedt $\mathrm{K}$ and Lundholm K: Preoperative treatment with a non-steroidal antiinflammatory drug (NSAID) increases tumor tissue infiltration of seemingly activated immune cells in colorectal cancer Cancer Immun 8: 5, 2008.

21. Pocock SJ and Simon R: Sequential treatment assignment with balancing for prognostic factors in the controlled clinical trial. Biometrics 31: 103-115, 1975.

22. Lönnroth $\mathrm{C}$, Andersson $\mathrm{M}$ and Lundholm $\mathrm{K}$ : Indomethacin and telomerase activity in tumor growth retardation. Int J Oncol 18: 929-937, 2001.

23. Axelsson H, Lönnroth C, Andersson M, Wang W and Lundholm K: Global tumor RNA expression in early establishment of experimental tumor growth and related angiogenesis following COX-inhibition evaluated by microarray analysis. Cancer Inform 2: 199-213, 2007.

24. Lundholm K, Gelin J, Hyltander A, Lonnroth C, Sandstrom R, Svaninger G, Korner U, Gulich M, Karrefors I, Norli B, Hafström L, Kewenter J, Olbe L and Lundell L: Anti-inflammatory treatment may prolong survival in undernourished patients with metastatic solid tumors. Cancer Res 54: 56025606, 1994.

25. Cahlin C: Cyclooxygenase activity and tumor progression. Gothenburg: University of Gothenburg, Thesis, 2008.

26. Lundholm K, Daneryd P, Korner U, Hyltander A and Bosaeus I: Evidence that long-term COX-treatment improves energy homeostasis and body composition in cancer patients with progressive cachexia. Int J Oncol 24: 505-512, 2004.

27. Wang W, Andersson M, Lönnroth C, Svanberg E and Lundholm K: Anorexia and cachexia in prostaglandin EP1 and EP3 subtype receptor knockout mice bearing a tumor with high intrinsic PGE2 production and prostaglandin related cachexia. J Exp Clin Cancer Res 24: 99-107, 2005.

28. Cahlin C, Lönnroth C, Arvidsson A, Nordgren S and Lundholm K Growth associated proteins in tumor cells and stroma related to disease progression of colon cancer accounting for tumor tissue PGE2 content. Int J Oncol 32: 909-918, 2008.

29. Huang RH, Chai J and Tarnawski AS: Identification of specific genes and pathways involved in NSAIDs-induced apoptosis of human colon cancer cells. World J Gastroenterol 12: 6446-6452, 2006.

30. Wise H: Multiple signalling options for prostacyclin. Acta Pharmacol Sin 24: 625-630, 2003.

31. Cutler NS, Graves-Deal R, LaFleur BJ, Gao Z, Boman BM, Whitehead RH, Terry E, Morrow JD and Coffey RJ: Stromal production of prostacyclin confers an antiapoptotic effect to colonic epithelial cells. Cancer Res 63: 1748-1751, 2003.

32. Hirai H, Tanaka K, Takano S, Ichimasa M, Nakamura M and Nagata K: Cutting edge: agonistic effect of indomethacin on a prostaglandin D2 receptor, CRTH2. J Immunol 168: 981-985, 2002.

33. Park JM, Kanaoka Y, Eguchi N, Aritake K, Grujic S, Materi AM, Buslon VS, Tippin BL, Kwong AM, Salido E, French SW, Urade Y and Lin HJ: Hematopoietic prostaglandin D synthase suppresses intestinal adenomas in ApcMin $/^{+}$mice. Cancer Res 67: 881-889, 2007.

34. Gosset P, Bureau F, Angeli V, Pichavant M, Faveeuw C, Tonnel AB and Trottein F: Prostaglandin D2 affects the maturation of human monocyte-derived dendritic cells: consequence on the polarization of naive Th cells. J Immunol 170: 4943-4952, 2003.

35. Yoshimura-Uchiyama C, Iikura M, Yamaguchi M, Nagase $H$, Ishii A, Matsushima K, Yamamoto K, Shichijo M, Bacon KB and Hirai K: Differential modulation of human basophil functions through prostaglandin D2 receptors DP and chemoattractant receptor-homologous molecule expressed on Th2 cells/DP2. Clin Exp Allergy 34: 1283-1290, 2004.

36. Yoshida T, Ohki S, Kanazawa M, Mizunuma H, Kikuchi Y, Satoh H, Andoh Y, Tsuchiya A and Abe R: Inhibitory effects of prostaglandin D2 against the proliferation of human colon cancer cell lines and hepatic metastasis from colorectal cancer. Surg Today 28: 740-745, 1998.

37. Park BH, Breyer B and He TC: Peroxisome proliferator-activated receptors: roles in tumorigenesis and chemoprevention in human cancer. Curr Opin Oncol 13: 78-83, 2001.

38. Backlund MG, Mann JR, Holla VR, Buchanan FG, Tai HH, Musiek ES, Milne GL, Katkuri S and DuBois RN: 15-Hydroxyprostaglandin dehydrogenase is down-regulated in colorectal cancer. J Biol Chem 280: 3217-3223, 2005. 
39. Quidville V, Segond N, Pidoux E, Cohen R, Jullienne A and Lausson S: Tumor growth inhibition by indomethacin in a mouse model of human medullary thyroid cancer: implication of cyclooxygenases and 15-hydroxyprostaglandin dehydrogenase. Endocrinology 145: 2561-2571, 2004.

40. Frenkian M, Segond N, Pidoux E, Cohen R and Jullienne A: Indomethacin, a COX inhibitor, enhances 15-PGDH and decreases human tumoral $C$ cells proliferation. Prostaglandins Other Lipid Mediat 65: 11-20, 2001

41. Glebov OK, Rodriguez LM, Lynch P, Patterson S, Lynch H, Nakahara K, Jenkins J, Cliatt J, Humbyrd CJ, Denobile J, Soballe P, Gallinger S, Buchbinder A, Gordon G, Hawk E and Kirsch IR: Celecoxib treatment alters the gene expression profile of normal colonic mucosa. Cancer Epidemiol Biomarkers Prev 15: 1382-1391, 2006.

42. Auman JT, Church R, Lee SY, Watson MA, Fleshman JW and McLeod HL: Celecoxib pre-treatment in human colorectal adenocarcinoma patients is associated with gene expression alterations suggestive of diminished cellular proliferation. Eur $\mathbf{J}$ Cancer 44: 1754-1760, 2008.
43. Bosserhoff AK: Melanoma inhibitory activity (MIA): an important molecule in melanoma development and progression. Pigment Cell Res 18: 411-416, 2005.

44. El Fitori J, Kleeff J, Giese NA, Guweidhi A, Bosserhoff AK, Buchler MW and Friess H: Melanoma Inhibitory Activity (MIA) increases the invasiveness of pancreatic cancer cells. Cancer Cell Int 5: 3, 2005.

45. Lönnroth C, Svaninger G, Gelin J, Cahlin C, Iresjö B-M, Cvetkovska E, Edström S, Andersson M, Svanberg E and Lundholm K: Effects related to indomethacin prolonged survival and decreased tumor growth in a mouse tumor model with cytokine dependent cancer cachexia. Int J Oncol 7: 1405-1413, 1995. 